\title{
Ecclesiological Renewal for a Relevant Ministry and Church Polity, with reference to UCCSA and UPCSA in Zimbabwe
}

\author{
Xolani Maseko \\ https://orcid.org/0000-0003-1684-4905 \\ University of Pretoria \\ xlnmaseko@gmail.com
}

\author{
Wim A. Dreyer \\ https://orcid.org/0000-0001-5373-5949 \\ University of Pretoria \\ wim.dreyer@up.ac.za
}

\begin{abstract}
This article is a critique of Reformed Ecclesiology, particularly as regarding ministry and church polity. It is argued herein that a static ecclesiology results in church ministry that is seemingly deficient in responding to the context. This is seen in the current church polities and ways in which different denominations explain and carry out their ministry in the face of the new religious environment of the 21 st century. This critique demands imperatives from the church, especially now in the advent of the emerging church, virtual ministry and such pandemics as Covid-19. The church cannot afford to remain ambivalent; her relevance is at stake. This article deals with Reformed Ecclesiology and polity in the context of Zimbabwe, with a special focus on the United Congregational Church of Southern Africa (UCCSA) and the Uniting Presbyterian Church in Southern Africa (UPCSA) in Zimbabwe. These two denominations are in a "prolonged" engagement for church unity. From a strategic perspective, a possible ecclesiology will be proposed that can facilitate this renewal in the context of a Calvinistic ecclesiology. It is argued that a change in ecclesiology will result in a refined church ministry and polity. This is done by investigating the "church as epiphany."
\end{abstract}

Keywords: United Congregational Church of Southern Africa (UCCSA); Uniting Presbyterian Church in Southern Africa (UPCSA); ecclesiology; ecumenism; manifestation; polity; eschatology; renewal

\section{UNISA}

Studia Historiae Ecclesiasticae https://upjournals.co.za/index.php/SHE/index Volume 47 | Number 1 | 2021 | \#8373 | 13 pages https://doi.org/10.25159/2412-4265/8373

ISSN 2412-4265(Online ) | ISSN 1017-0499(Print)

(C) The Author(s) 2021 


\section{Introduction}

In 2017, Reformed churches celebrated five centuries of church reformation. One wonders, if the Reformers were to come to life today, would they still speak about the church in a similar manner as during the 16th century? The concept of ecclesia semper reformanda has widely been adopted by many churches and theologians in their ecclesiological discourse. It was Karl Barth (1947, 24-37) who reminded us that once the church is reformed, it must always keep on reforming. Koffeman and Smit (2014) imply with the title of their book, "Protestant Church Polity in Changing Contexts II," that any static ecclesiology, church polity or ministry may suffer problems of relevance because the context is ever changing. This is what they argue in the preface: "In a globalising world all churches have to deal with changing contexts ... Protestant churches are continuously challenged by such changes" (Koffeman and Smit 2014, v). Reformed churches in the Calvinist tradition are constantly challenged in terms of ecclesiological relevance and the seemingly slow pace of renewal.

This article ${ }^{1}$ is a critique of Reformed Ecclesiology, particularly regarding ministry and church polity. It is argued herein that a static ecclesiology results in church ministry that is seemingly deficient in responding to the context. However, Reformed churches cannot afford to remain ambivalent - their relevance is at stake. This article deals with Reformed Ecclesiology and polity in the context of Zimbabwe, with a special focus on the United Congregational Church of Southern Africa (UCCSA) and the Uniting Presbyterian Church in Southern Africa (UPCSA). The contribution also investigates the possibilities for renewal by using the concept of "the church as epiphany."

\section{Ecclesiology, Polity, Ministry}

Dreyer (2013, 1-5) writes that ecclesiology must change and become missional if it is to inspire a change. He argues that "there is a direct interdependency of ecclesiology, church polity and ministry; church polity and church order is based on ecclesiology." If we apply this to the Reformed tradition, we will note a direct link between Calvin's ecclesiology and the way Reformed churches view ministry and church offices, as articulated in various church orders. As an example, Calvin (1959[2002]) describes the signs of the true church (notae ecclesiae) as follows (Inst. 4.1.9):

Hence the form of the church appears and stands forth conspicuous to our view. Wherever we see the word of God sincerely preached and heard, wherever we see the sacraments being administered according to the institution of Christ, there we cannot have any doubt that the church of God has some existence, since his promise cannot fail, "where two or three are gathered together in my name, there am I in the midst of them."

This formulation is central to the Reformed idea of a true church and was reiterated in the Reformed confessions. The "Belgic Confession" (Article 29) reads: "We are

1 This contribution is submitted as a requirement for the degree $\mathrm{PhD}$ (Church History and Church Polity) in the Department of Systematic and Historical Theology, University of Pretoria. 
speaking of distinguishing the body and fellowship of the true church ... the church engages in the pure preaching of the gospel; it makes use of the pure administration of sacraments as Christ constituted them; it practices church discipline for the correction of faults."

These marks determine polity and ministry in the Reformed churches. It is apparent that the offices of the ordained minister and elder follow from what are considered to be the marks of the true church. The "Belgic Confession" in article 30 says, "we believe that this true church should be governed according to the spiritual order that our Lord has taught us in his word. There should be ministers or pastors to preach the word of God and administer the sacraments. There should also be elders and deacons along with pastors to make up council ..." Herein we see the understanding of the office and especially the ordained ministry related to the discharge of the ministry of the word and sacrament, which are considered to be the pillars of a true church by Calvin. This view of the church comes into scrutiny in the light of emerging churches that do not seem centred around the ministry of the offices in preaching the word and administering the sacraments at a designated place.

This Calvinistic understanding of ecclesiology, in relation to the marks of the true church, can be seen in the understanding of the ordained ministry in UCCSA and UPCSA in Zimbabwe. The ordained ministry is understood functionally as set in place for the preaching of the word and administration of sacraments. This understanding of the purpose of ordination is viewed in herein as narrow, and reflects some seeming inadequacies in the way the church does polity in the present context. For two weeks into April 2020, the nation of Zimbabwe had been caught up in a lockdown due to the Covid-19. The Good Friday and Resurrection Sunday (both commonly referred to as Easter) were celebrated without the church gathering physically. Each member observed this considered sacred time from their homes. Many churches, especially the Pentecostal Charismatic churches, had as part of their online liturgy and ministry the celebration of the Eucharist. UCCSA, which is a Calvinistic Reformed Church, did not partake of the Eucharist, particularly on Maundy Thursday, as is the tradition. In a telephonic interview with the General Secretary, Reverend K Ndebele, who articulated the position from the Denominational Officers and the Theological Commission, he said that the sacraments are part of the church's pillars, therefore, at the moment allowing them to online ministry will be opening them to abuse (telephonic interview on 07/04/2020). In talking with the Presbytery Clerk of Zimbabwe for UPCSA, Reverend L Neshangwe, she said that they could not have the celebration online, it would be done once the lock down was over (telephonic interview on 14/04/2020). This may be seen as following a Calvinistic understanding of the church and sacraments that are normally celebrated in some place in the context of a church gathering, and with the ordained minister presiding or someone who has been commissioned and licensed for it.

It is, therefore, clear that in the Reformed Ecclesiology, though it has the intention to pursue being a missional church, the rigidness in ecclesiology hampers the missional 
progress. This is seen in the way the churches do church polity and ministry. This reflects some inadequacies in terms of being relevant to the challenges of the $21 \mathrm{st}$ century. The ecclesiological foundations of the Reformation churches may have served well in their context in history, but they seem inadequate for the current context of postmodernity. The current context is calling for a new paradigm in how "church" is perceived and practised.

\section{Historical Considerations}

The current context of the Reformed Ecclesiology has the need to understand Calvin in his context of the 16th century, and apply him to current contexts. In this way, such a reinterpretation may fit in the call for ecclesia semper reformanda. Polity and ministry can then learn and find inspiration for mutation and transformation to better serve the current religious climate. Calvin's context was one of an absolute hierarchical structure in church with the Pope as the vicarius Christi and head of the church on earth. The clergy wielded much power over the laity. Talking about this, Tanner $(2008,34)$ tells us of "the paradoxes of high authority, the fact that office holders were frail human beings, often leading sinful lives, and the service involved in all authority ..." Furthermore, the Roman Catholic Church embraced sacramental theology in every sphere. Even ecclesiology was sacramental. The church was seen as the ark of Noahonly those who were inside were saved. So, the Catholic Church taught that outside the church there is no salvation. They learnt this from Cyprian who, according to Edward (1897, 33), taught that "the bishop is the sacrificing priest. Christ was himself the Ordainer of the Jewish priesthood. The priests of that line were 'our predecessors' ... its reality passed on to the bishop." As a result, the clergy were elevated in status as people who perform the sacrifice of Christ in the Eucharist.

A context such as that of the 16th century, medieval Roman Catholic Church is seen to have influenced the Reformers. In their theology there may have been transmitted some elements of protest. For example, Calvin protested the headship of the Pope over the church; thus, in his ecclesiology the point of departure was that only Christ was the head of the church (see Calvin 1959[2002] Inst. 4.3). He moved away from a hierarchical structure, and one of the reasons (other than scriptural conviction) was probably due to his context and the possible abuse of that church structure. It is understandable from this contextual view why, in his ecclesiology, he emphasised the office of elder and discipline - because this would act as a balancing mechanism so that those in church offices do not abuse office. True as this may be, the context has changed, the Reformed churches are confronted with new mission frontiers that demand a new approach. It may not mean a complete overhaul of ecclesiology, as left by Calvin, but it may mean removing the emphasis on certain aspects and putting an emphasis on others-for the sake of mission in context.

Sola Scriptura was a key principle for all the Reformers. It ought to govern how the Reformed churches do church today. The traditions inherited from the Reformers were arrived at because of the convictions they had during their time concerning the scripture. 
If seeking fidelity to the scriptures as they were, they would not be amused to find their successors still holding on dogmatically to their ideas, even in the face of new revelation from the scripture. The words of John Robinson, who was a Calvinist himself, and one of the ancestors of Congregationalism, are perfectly suited to guide "ecclesia semper reformanda" in the current discourse for the need of Reformed ecclesial renewal. He said:

I charge you before God ... that you follow me no further than you have seen me follow the Lord Jesus Christ. If God reveals anything to you by any other instrument of His, be as ready to receive it as you were to receive any truth by my ministry, for I am verily persuaded the Lord hath more truth yet to break forth out of His Holy Word. For my part, I cannot sufficiently bewail the condition of those Reformed churches which ... will go, at present, no further than the instruments of their reformation. The Lutherans cannot be drawn to go beyond what Luther saw; whatever part of His will our God had revealed to Calvin, they will rather die than embrace it; and the Calvinists, you see, stick fast where they were left by that great man of God, who yet saw not all things. This is a misery much to be lamented. ${ }^{2}$

This speaks of the need for the scriptures to be the guiding light in every age and in every context. Scriptural interpretation must speak to our ecclesiology. Ecclesiology will, in turn, speak to how we do polity.

\section{Hermeneutical Considerations}

Reformed churches base their ecclesiology on the scripture. As the Christian Reformed Church (CRC) notes in $(2016,7)$, "Paul makes a great deal of the fact that the body of Christ is one (1 Cor 12:12; Eph 4:4-6)." Similarly, Reformed churches understand themselves as the body of Christ who is the head of the church according to scripture (Col 1:18 and Eph 1:23). It follows that Reformed churches reject any headship office over the church, they reserve this for Christ alone. Christ rules over the church through offices according to the legacy from Calvin (1959[2002] Inst. 4.1.9), which tells us that it is in the ministry of the offices that the marks of the church are located; that is sincere preaching of the word and administration of the sacraments in accordance with the institution of Christ. This defines the church that is gathered according to the promise of the Lord that "where two or three are gathered together in my name, there am I in the midst of them" (Matt 18:20).

UCCSA's understanding of polity with regard to the understanding of the ordained ministry is kind of inadequate, as would be the case with many protestant and Reformed churches. According to the book on the polity of UCCSA (Briggs 1996, 100), talking about covenant ministry under the ordained ministry, it is stated: "In the old covenant God called those who would serve him ... a Congregationalist minister is the one who

2 Rick, on his blog wrote: "The Timeless Words of John Robinson." The Pilgrim Spirit. Accessed 16/04/2020. https://www.newtestamentpattern.net/christian-articles/sundry-thoughts/the-words-ofjohn-robinson_mayflower/. 
hears Christ's call to serve him as a minister of the word and sacraments. In answering that call, the prospective minister is tested by the church before going for training." This is Calvinistic in essence in terms of the call process of the ministers and the understanding of ministry. UPCSA also teaches that, within the "priesthood the Church has from its very early days recognised the need for Ministers who are called, trained, equipped and ordained to preach the Word, to administer the Sacraments, to care for all those in their charge, and, together with the Elders, to rule" (UPCSA 2007, chap16.1). This again is influenced by Calvin's ecclesiology. This kind of worship and ministry seems to be centred on the person of the ordained minister and the visible church. This article sees herein a gap for the development of an ecclesiology where worship and ministry, though facilitated by an ordained minister, may have Jesus at the centre.

Ecclesiological renewal is needed in the Reformed churches if the possibility of church unity and the ecumenical polity is to be realised. In this case, ecumenical polity comes to bind the fellowship and governance of a united church. Polity becomes a servant of ecclesiology. In order to illustrate this truth, an observation can be made on UCCSA and UPCSA's proposed union, whose memorandum was signed in October 2017 (Booth $2017,1)$. It was meant to serve the churches for five years before the envisaged union would take place. Now, in 2020, with only a year to go, churches are still in a struggle of finding each other, largely on questions of polity, interests and resources. Seeing that these churches are in the same tradition, there must be no polity qualms. However, they are embroiled in differences in the way they understand the Reformed polity between Presbyterianism and Congregationalism. This shows that even these historicalecclesiological traditions are not absolute and sometimes do impede mission. Koffeman $(2015,4)$ has advice regarding such a renewal:

The New Testament does not offer one church-order model—be it episcopal, or Presbyterial-synodical, or Congregationalist-but rather a variety that depends on historical and contextual factors as well as practical needs. New Testament texts cannot be applied directly in a church order. In my Reformed tradition, 1 Corinthians 14:40 has played a major role: " $[D] \mathrm{o}$ everything properly and in order" (Contemporary English Version). This reference might be to the point, albeit in a way slightly different from its traditional interpretation that focused on the sheer need to organise church life. On the

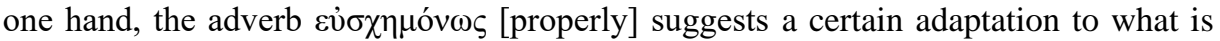
understood as accepted norms in a specific context: the church should not be unnecessarily provocative nor get itself talked about. On the other hand, the words $\kappa \alpha \tau \grave{\alpha}$ $\tau \alpha \dot{\xi} \xi \nu$ (in order) refer to what was a common understanding in the Hellenistic context in which the New Testament is written: there is a relationship between God and "what is good," "harmony," or "world order" (cf. 1 Cor 14:33: "God wants everything to be done peacefully and in order").

If the scripture (New Testament) does not prescribe a church order, the imperative for church unity and ecumenical action - which is grounded on sound theology-must necessitate a change in ecclesiology. This will result in a new polity being coined to serve the envisaged united church. 


\section{The Church as Epiphany}

Hans Küng $(1964,29)$ argues in his book, "The Structures of the Church," that a multiplicity of church denominations must not be taken as an indication of disunity. Diversity does not mean division, and as such the re-union of churches must be expected because "it is fitting that the inner spiritual unity of the church should be manifested outwardly." This inner unity comes from the invisible nature of the church. It is from this description of unity manifesting from the inner reality, that inspiration was got to emphasise the invisible nature of the church and expect this reality to influence the outer manifestation of the church (visible church).

According to Kärkkäinen $(2002,52)$, "For Calvin, the church is primarily a visible community. One motif that helped Calvin to stress the visible side of the church was his growing emphasis on the public appropriation of sacraments, especially baptism." In the interest of ecclesiological renewal of the Reformed tradition, it is proposed that there should be an emphasis of the invisible church over its visible form. It is understandable for Calvin to put eminence on the visible church because, as a lawyer, he was concerned with church order and law in the context of the 16th century reformation. This could be achieved by understanding the church as epiphany.

"Epiphania" is from the Greek and Latin meaning "manifestation." Epiphany is the manifestation of God in and through Jesus Christ. If the church is understood as the body of God, it could be argued that God manifests in and through the church as the body of Christ, which is something different than a denominational structure. According to Reformed Ecclesiology, "where there is pure preaching and the correct administration of the word of God," there is the true church (Calvin 1959[2002] Inst. 4.1.10). Herein, it is proposed to add another mark, the lived reality of faith. Lived faith refers to life in the kingdom of God, manifesting in a transformed life of a person and a community. It is an eschatological life in whichever context the church is. In a way, it points to a communion ecclesiology, where the church is a community of faith in communion with the Trinity (Tjorhom 2010, 894). Communion ecclesiology facilitates church unity.

An "epiphany ecclesiology" maintains the basic principle of Reformed Ecclesiology, namely Jesus Christ as the only head of the church. This church is first and foremost an invisible entity. This invisible reality then manifests itself through and in the visible church. The visible church is a form in which the invisible church manifests, even though such a manifestation is not dependent on locality or gathering. It surely includes the world around the visible church. It is the company of those whose names are written in the book of life in heaven. Herein, there is no room for hierarchy in church structure and leadership. Whereas in Calvinistic tradition, as seen in UCCSA and UPCSA, there is value in the concept of the gathered church in a certain locality, an epiphany ecclesiology extends the concept of the gathered church to include "virtual congregation." This means one can be part of a worship service being physically absent but spiritually present without being physically present in a church worship service. Sacraments do not necessarily need to be celebrated with others in a particular place; 
the minister (ordained or licensed laity) can still serve one person with the sacraments outside of a church gathering. This is very different from the known Reformed Ecclesiology that UCCSA holds to the value of a gathered church (see Model Constitution for Local Churches, Union Commission UCCSA and UPCSA 2007, 3.1). The same is true for UPCSA (see Manual of Faith and Order 2007, 1.1).

In the pursuit of epiphany ecclesiology, the advice of Karl Barth (1959-1975 CD IV.1, 669) is heeded - as learnt from Dreyer (2016, 7-8) - that the church does not have two natures but one, in which the invisible manifests in the visible. This must be understood in terms of his emphasis on revelation as a source of theology. This implies that the spiritual aspect of the church manifests in the natural; and that is what this article proposes as epiphany. The empirical church should reflect the church which we believe is the body of Christ, the temple of the Holy Spirit, the family of the Father and the people of God. Even though some may argue that Barth in his dogmatics was correcting the emphasis on two natures of the church, namely visible and invisible, this does not take away the revelation, epiphany or manifestation of the divine aspect of the church. Building on that argument is what this article calls epiphany ecclesiology.

In this proposed epiphany ecclesiology, church offices remain as they stand in the Reformed tradition. However, unlike the Reformed tradition, where the ministry of the word and sacraments is limited to a particular place within the gathered congregation, in the proposed epiphany model, these sacraments can be received anywhere and anytime, as long as there is a person who is commissioned. The whole earth is seen as holy ground. The world is sacred, as it is the arena of the manifestation of the church from its invisible nature, which is tied to the kingdom of God. This includes a virtual platform, as long as there is a prayer of consecration at that moment. Individual believers have been called to represent the invisible church in the world. This speaks of the invisible church as a manifestation of the kingdom of God and the priesthood of all believers.

One can ask the question regarding the sources of the proposed "epiphany ecclesiology." This learns much from Reformed Ecclesiology. It adopts almost all Reformed ecclesiological principles, except for minor changes which could lead to significant results. The changes are in the emphasis on the invisible rather than the visible nature of the church; in a move away from an overly institutionalised to a more organic understanding of the church. Also, on top of the two held marks of the church, another one is added, namely a "lived faith." These convictions are born from scripture (Hebrews 12:22-23) which testifies that the church is the company of innumerable and invisible people whose names are written in the book of life. The mark of lived/practical faith is also evident in James 1:27 and Matthew 7:21-23. This perspective of a "lived faith" in the community and doing the will of God fits in perfectly with the understanding of missional ecclesiology (see Hooker 2008, 1-2). 
The notion of the manifestation of the kingdom of God through lived faith in the community, has some roots in the theology of Bonhoeffer when he speaks of "religionless Christianity" in context of the church struggle against the Nazi's in Germany. Bethge (n.d., www.santuarycrc.org, accessed April 20, 2020), speaks of the church outside the established church, which he calls a "life in Christ": He speaks of brothers and friends, men and women, who did not find easy access into their existing churches but who nevertheless took responsibility for the situation. These include modest and humble scientists, defeated politicians and desperate soldiers, those involved in the conspiracy against Hitler, and others. Bonhoeffer, the churchman and theologian, was among them.

If these people would be sharing what the church is outside the institutions of the church, it shows that the church is more than a denominational institution. In Luke 9:50, Jesus says: "Do not stop him, for whoever is not against you is for you" (NIV). The dream of an "epiphany ecclesiology" flows from the understanding that God is present in the world (missio Dei) in many diverse ways, not only in and through denominational structures.

In the contemporary ecclesiological discourse one of the favoured terms for describing the ideal ecclesiology is "incarnational." Kärkkäinen $(2002,26)$ notes that in Catholic Ecclesiology it is argued that the church is a continuation of the incarnation of Christ. This is in line with the understanding of the church as the communion of the Trinity. Niemandt $(2012,4)$ talks about the "true" church being incarnational, universal and contextual. It has to be understood that the "incarnational" model is an ideal for all church denominational traditions. What "epiphany ecclesiology" calls for, are the means of the Reformed Church reaching a state where it can be described as relevant and contextual to the current world and ecclesial climate. This could be achieved through a shift in emphasis from the visible to the invisible aspect of the church and the strong teaching and orientation towards a new additional mark of the church, which is lived reality of a transformed life. Even though this concept can inspire and impact other church traditions, it is proposed with a particular focus on the churches in the Reformed tradition.

\section{"Epiphany Ecclesiology" with reference to UCCSA and UPCSA}

The history of union talks involving the two churches dates back to the 1970s, where such talks were involving the Methodist Church as well. This was before the Presbyterian Church of Southern Africa (PCSA) and the Reformed Presbyterian Church in South Africa (RPSA) had merged to form UPCSA in 1999. The unity talks are contained in the Model Constitution of the Unity Commission (2007, iii) which states the following:

To seek the Union of the Church of the Province of Southern Africa, the United Congregational Church of Southern Africa, the Methodist Church of Southern Africa, 
the Presbyterian Church of Southern Africa, the Evangelical Presbyterian Church in South Africa and the Reformed Presbyterian Church in Southern Africa.

We believe that God redeems His world through Jesus Christ and that He calls His church to share in this mission. In humble penitence, we recognise that our divisions impair our witness to Christ in the world today.

We believe that it is God's will that His church should be a visible one, and that the Holy Spirit is moving us to seek this union.

The unity talks were confirmed after UPCSA was formed, now without the Methodist Church. The talks were abandoned and later resurfaced in 2017, when the memorandum of understanding was signed between UCCSA and UPCSA (Booth 2018, 1-10). The signed memorandum states that the talks will be carried on for five years, after which in 2022, the envisaged union must be achieved. Up to as late as 2020, the discussions have not covered much ground.

The reason that makes the talks to be revived all the time (after such a long history of failure) may be due to the fact that the Holy Spirit is moving in the church and the churches are already united in their invisible nature. It is the argument of this article that the reality of failure to achieve the envisaged united church is highly probable because of the two denominations engaging from a perspective of ecclesiology that is based on the visible nature of the church. This entails engagement from the church as an institution, with its history, polity and resources rather than proceeding from an understanding of ecclesiology which says, if it is the will of the Holy Spirit, then it must be achieved. The latter approach (epiphany ecclesiology) may lead the two denominational institutions in agreeing to compromise their positions; after all, the two denominations claim the same Calvinistic Reformed tradition. Bonhoeffer (in Clements 2015,98 ) had the following to say about church unity:

The church as a genuine form is unity, basically the unity of God! The form reveals itself under the presupposition of unity. Differentiation: the church over against a religious community (arisen from individual converging wills) [is necessary]. The church is the primary unity. Those who do not start with unity confuse the church with a religious community.

It is from such a view that this article argues that the manifestation of unity in the church, in terms of different denominations coming together, is from the invisible church that is united in Christ.

Both UCCSA and UPCSA are members of the Council for World Mission (CWM), whose vision is about building missional churches. Woods $(2014,1)$ tells us that the CWM adopted the vision for developing missional churches into their strategy. In the past decade, UCCSA and UPCSA have both been involved in the dialogues of how to refocus the churches from maintenance to mission. This found contextual significance 
in the theological discourse about missional ecclesiology that has and is dominating academia. It is seen as a means of relevance in the contemporary post-modern context. This challenges the church to participate in what God is doing (missio Dei) in the world, rather than creating programmes for churches. It is a realisation that God is already at work in the world, with or without the church in its visible form (see Dreyer 2013, 15). This new proposed version of Reformed Ecclesiology (epiphany ecclesiology) suits the missional paradigm as it puts emphasis on the manifestation of the church in the community through the works of faith in God. This learns from John 17:18, in which Christ prays, "as you have sent me into the world, even so have I sent them."

\section{Conclusion}

In conclusion, the words of Dreyer $(2013,4)$ are worth repeating: "The way we understand the church, defines our church polity which in turn influences the congregational praxis and ministry. Even more, the way we understand God reflects in the way we understand the church and its calling in this world."

This speaks of what it means to be a missional church and the need for renewal in a post-modern context. The renewed ecclesiology that is dreamt of in this article is one which emphasises the invisible nature of the church over its visible one. It is the one that teaches on the three marks of the true church. These are the preaching of the word, the administration of sacraments, and a lived faith in the community. These three elements, together with the emphasis on the invisible nature of the church, must result in a church that manifests the Kingdom of God in the society. It is from this that the term "epiphany ecclesiology" is derived.

UCCSA and UPCSA, as Reformed churches, can benefit from such a renewal in ecclesiology in their pursuit of unification, and being true to the imperative of a missional church. Such a change in ecclesiology will result in a change in church polity and ministry. It is further believed that such a renewal will enhance the church's involvement in ecumenism. The Baptism, Eucharist and Ministry (BEM) declaration has long been adopted by a majority of churches. It speaks of unity in that it is a document of convergence, but the contradiction is that though churches have approved it, in practice church splits and denominationalism are still common. ${ }^{3}$ This tells us that we are far from unity and far from each other, yet it is a common document on which we must all find each other. The challenge, then, is that we must refine our ecclesiologies in order to live this polity and liturgy document. Polities and liturgy must be welcoming to people, with elements of humility knowing that church is more than a building, a gathering and the name of a denomination. It has to do with the manifestation of the kingdom of God in our lives and ultimately in the eschaton which is the reality of consummation of the kingdom of God. 


\section{References}

Barth, K. 1947. "Die Botschaft von der freien Gnade Gottes.” In Theologischen Existenz heute Heft 9, 24-37, edited by K. G. Steck and G. Eichholz. München: Kaizer Verlag.

Barth, K. 1956-1975. Church Dogmatics, Vol. I-XXXI, revised edition, translated by G. T. Thompson, H. Knight, G. W. Bromiley, and T. F. Torrance. T\&T Clarke.

Bethge, E. (n.d.) “Bonhoeffer's Christology and His 'Religionless Christianity'.” Accessed April 20, 2020. www.sanctuarycrc.org.

Briggs, R. D. 1996. A Covenant Church. Studies in the Polity of the United Congregational Church of Southern Africa. Gaborone: Pula Press.

Calvin, J. 1959[2002]. Institutes of Christian Religion, translated by H. Beveridge and edited by R. J. Dunzeweiler. Accessed April 16, 2020.

http://www.ccel.org/ccel/calvin/institutes.titlepage.html.

Clements, K. 2015. Dietrich Bonhoeffer's Quest. Geneva: WCC Publications. https://doi.org/10.1111/erev.12162.

CRC. 2016. "What it Means to be Reformed.” Accessed May 17, 2020. www.crena.rg.

Dreyer, W. 2013. "Missional Ecclesiology as Basis for New Church Oder: A Case Study.” HTS Teologiese Studies/Theological Studies 69 (1), Art \#1368. https://doi.org/10.4102/hts.v69i1.1368.

Dreyer, W. 2016. "Church Mission and Ethics. Being Church with Integrity.” HTS Teologiese Studies/Theological Studies 72 (1): a3163. https://doi.org/10.4102/hts.v72i1.3163.

Edward, B. 1897. Cyprian, His Life, His Times, His Work. London: McMillan.

Kärkkäinen, V. M. 2002. An Introduction to Ecclesiology. Ecumenical, Historical and Global Perspectives. Downers Grove, IL: Intervarsity Press.

Koffeman, L. J. 2015. “Ecclesia Reformata Semper Reformanda. Church Renewal from a Reformed Perspective.” HTS Teologiese Studies/Theological Studies 71 (3). https://doi.org/10.4102/hts.v71i3.2875.

Koffeman, L. J., and J. Smit (Eds). 2014. "Protestant Church Polity in Changing Contexts II. Case Studies." Proceedings of the International Conference. Utrecht, The Netherlands, 710 November, 2011. Zurich: Lit. Verlag GmbH, KG Wien.

Hooker, P. 2008. "What is Missional Ecclesiology?” In Northeast Georgia Presbytery. Accessed March 20, 2020. http://www.negapby.org/missionalecc,pdf.

Küng, H. 1964. Structures of the Church, translated by Salvator Attensio. Notre Dame: University of Notre Dame Press. 
Niemandt, C. J. P. 2012. “Trends in Missional Ecclesiology.” HTS Teologiese

Studies/Theological Studies 68 (1): Art. \#1198. https://doi.org/10.4102/hts.v68i1.1198.

Tanner, N. 2008. The Church in the Later Middle Ages. London: I. B. Tauris. https://doi.org/10.5040/9780755624843.

Tjorhom O. 2010. Ecclesiology of Communion: On the Church as a Vertically Committed Fellowship. Kristiansand. Norway: The University of Adger.

WCC. 2013. Faith and Order, Paper No. 214. Geneva: WCC Publications.

Woods, P. 2014. "CWM Perspective on Missional Congregations as Life-Affirming Communities.” CWM: https://doi.org/10.1111/irom.12042.

\section{Internet Sources}

"Belgic Confession.” Accessed April 15, 2020. www.crcna.org.

“The Timeless Words of John Robinson.” The Pilgrim Spirit. Accessed April 16, 2020. https://www.newtestamentpattern.net/christian-articles/sundry-thoughts/the-words-ofjohnrobinson_mayflower/.

\section{Unpublished Sources}

Booth, I. 2017. UCCSA/UPCSA Union. Unpublished paper.

UCCSA. 2013. United Congregational Church of Southern Africa Constitution (adopted in the 37th Assembly in Mmabatho 18-24, 2013).

Union Commission (UCCSA and UPCSA). 2007. Church Unit Commission Model Constitution for a United Church Trust and Congregation.

UPCSA. 2007. The Manual of Faith and Order of the Uniting Presbyterian Church in Southern Africa.

\section{Interviews}

Ndebele, K. Telephonic interview: UCCSA General Secretary, April 7, 2020.

Neshangwe, L. Telephonic interview: Presbytery Clerk of UPCSA in Zimbabwe, April 14, 2020. 